\title{
Econometric model for forecasting electricity demand of industry and construction sectors in Vietnam to 2030
}

\author{
Viet-Cuong VO ${ }^{1, *}$, Hoang-Phuong NGUYEN ${ }^{1,2}$, Le-Duy-Luan NGUYEN ${ }^{3}$, Van-Hung PHAM ${ }^{1}$
}

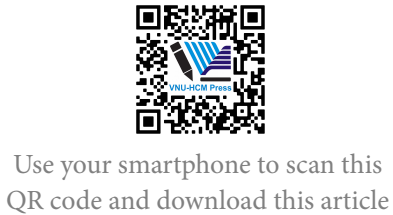

${ }^{1}$ Ho Chi Minh City University of Technology and Education, No.1, Vo Van Ngan Street, HCMC, Vietnam

${ }^{2}$ Tien Giang University, No.119, Ap Bac Street, Ward 5, My Tho, Tien Giang

${ }^{3}$ University of Architecture Ho Chi Minh City, No 196, Pasteur Street, District 3,

HCMC, Vietnam

\section{Correspondence}

Viet-Cuong vo, Ho Chi Minh City University of Technology and Education, No.1, Vo Van Ngan Street, HCMC, Vietnam

Email: cuongvv@hcmute.edu.vn

History

- Received: 15-12-2019

- Accepted: 13-3-2020

- Published: 31-3-2020

DOI : 10.32508/stdjet.v3i1.646

\section{Check for updates}

\section{Copyright}

(.) VNU-HCM Press. This is an openaccess article distributed under the terms of the Creative Commons Attribution 4.0 International license.

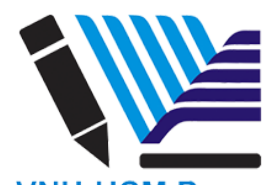

VNU-HCM Press

\begin{abstract}
An accurate forecasting for long-term electricity demand make a major role to the planning of the power system in any country. Vietnam is one of the most economic developing country in the world, and its electricity demand has been increased dramatically high of about 15\%/y for last three decades. Contribution of industry and construction sectors in GDP have been increasing year by year, and are currently holding the leading position of the largest consumers with more than 50\% sharing in national electricity consumption proportion. How to estimate correctly electricity consumption of these sectors takes a crucial contribution for the planing of the power system. This paper applies econometric model with Cobb Douglas production function - a top down method to forecast electricity demand of the industry and construction sectors in Vietnam to 2030. Four variables used are value of the sectors in GDP, income per person, proportion of electricity consumption of the sectors in total, and electric price. Forecasted results show that the proposed method has a quite low MAPE of $7.66 \%$ for a long-term forecating. Variable of electric price does not affect to the demand. This is a very critical result of the study for authority governors in Vietnam. In base scenario of the GDP and the income per person, the forecated electricity demands of the sectors are 112,853 GWh, 172,691 GWh, and 242,027 GWh in 2020, 2025, 2030, respectively. In high screnario one, the demands are 115,947 GWh, 181,591 GWh, and 257,272 GWh, respectively. The above vaules in the high scenario are less than from $9.0 \%$ to $15.8 \%$ of that of the based of in the Revised version of master plan NO. VII.

Key words: Forecast, Econometric model, Electricity demand, Cobb Douglas production function, Industry \& construction sectors
\end{abstract}

\section{INTRODUCTION}

An accurate forecasting for long-term electric loads can make a major contribution to the planning of a national power system. Forecasting electric load demand in consideration with its definite duration could be applied to build up long-term maintenance schedules, to establish the development and construction plan for new power-facilities, and expansion plan for transmission and distribution systems. The accuracy of a long-term forecasting model will lead to the feasibility and rationality of the future production and distribution development plan of power enterprises. An overestimating of demand can result unexpected effects on financial terms; while an underestimating will not only lead to the lack of power supply, but also injure the satisfactory of consumers or even damage to the national economy and society. Therefore, forecasting power demand for industry and construction sectors is an important compulsory.

Industry and construction sectors are the two biggest sectors which contribute more than $40 \%$ of Vietnam's gross domestic production (GDP). In order to meet that contribution, more than $50 \%$ of Vietnam electricity consumption has been delivered to that two sectors; in which some huge consumers could be identified as cement industry, steel - making factories, food processing facilities and beverage manufacturers, textile industry, etc...

Consumption of those industries has been increased significantly in recent years ${ }^{1}$.

Worldwide-studies on forecasting long-term electric load demand over the last decades are mainly focused on applying artificial neural network (ANNbased models) ${ }^{2}$, and econometric model (i.e. Cobb Douglas) into planning process ${ }^{3}$. ANN-based models have been implemented successfully in many countries due to its flexibility, high accuracy in terms of forecasting, good adaptation and processing ability on fluctuant data. However, when applying into Vietnam's context, ANN cannot prove its mentioned strengths because historical data on national and partial electric consumption was not fully recorded.

Cobb Douglas production function is an econometric approach which combines different statistical techniques and economic theories to forecast long-term 
power demand and electricity consumption. This method has been widely applied in researches of developing countries, such as Malaysia ${ }^{4}$, Pakistan $^{5}$, and China $^{6}$, etc. The strengths of Cobb Douglas production function are that: (1) it provides detail information about the stable and the changeability of variables and forecasted values; (2) it could be used to investigate the influential factors or variables impacting on forecasted results; and (3) it is a practical method which is easy to be analyzed and calculated ${ }^{7}$. Despite all these advantages, there is no record about experience on applying this method in forecasting long-term electricity demand for the industry and construction sectors.

\section{METHOD AND DATA}

\section{Cobb Douglas production function}

A Cobb Douglas production function is expressed in a non-linear form as $^{2}$ :

$E C_{t}=\varphi G_{t}^{\beta 1} I_{t}^{\beta 2} X_{t}^{\beta 3} P_{t}^{\beta 4}$

Where $E C_{t}$ is the consumption of industry and construction sectors in the year $\mathrm{t} ; G_{t}, I_{t}, X_{t}$, and $P_{t}$ are represented for the GDP of industry and construction sectors, income per person (US\$/person), proportion of industry and construction sectors' electricity consumption in total, and electric tariff in the year $t$, respectively. The technological parameter is indicated by $\varphi ; \beta_{i}$ are returns to scale linked with the four variables.

A logarithmic transformation is applied for two sides of the equation (1) to linearize it to become a linear form as:

$\ln E C_{t}=\beta_{0}+\beta_{1} \ln G_{t}+\beta_{2} \ln I_{t}+\beta_{3} \ln X_{t}+$ $\beta_{4} \ln P_{t}$

\section{Testing}

In other to evaluate the accuracy of econometric model, many testing methods have been recorded. Testing methods are computed with aims to maximize the accuracy and reliability of forecasting equation. For those researches proving the causality between variables, the date in time series should be tested the stationary (Augmented Dickey Fuller (ADF) or Phillips-Perron (P-P)) to avoid the spurious regression. After stationary test, the causality between variables is proven by using Granger causality test. For forecasting purpose, stationary test only is enough.

\section{Stationary test}

In order to ensure the sustainability of this study, two unit root test namely ADF and P-P are employed to test the stationary of prediction function. They are employed to avoid the spurious regression or nonsense regression when applying regression algorithm onto a non-stationary time series data. If there are some non-stationary series, to solve the problem, the first difference $(\Delta)$ of the series is done, then eliminating inappropriate variables. If all series are nonstationary, it leads to take the first difference of all variables, then removes the primary features of the series. However, it leads to the low $\mathrm{R}^{2}$ in regressing. The low $\mathrm{R}^{2}$ means the low accuracy of the prediction. To avoid the low of $\mathrm{R}^{2}$, co-integration test is conducted.

\section{Cointegration test}

Engle and Granger (1987) ${ }^{8}$ supposed the linear combination between non-stationary time series can be a stationary series and these non-stationary time series are co-integrated. The non-stationary linear combination is called co-integration equation and can be explained as the balance relationship between variables in long-term. Therefore, if variables co-integrate, the regression can be conducted. In this article, Johansen trace test is utilized to test the co-integration. In the Trace test (T-test), there are some hypotheses $\mathrm{H}_{0}$ listed as follow: "None", means there is no cointegration; "At most $1 ; 2 ; 3 \ldots$, means there is 1 , or 2 , or 3 co-integrations. To decide if we should reject or accept hypothesis $\mathrm{H}_{0}$, Trace Statistic value and Critical Value of $5 \%$ are compared. If Trace Statistic $<$ Critical Value, accept $\mathrm{H}_{0}$; if Trace Statistic $>$ Critical Value, reject $\mathrm{H}_{0}$.

\section{$R^{2}$ test ( $R$ square) and $p$-test}

$\mathrm{R}^{2}$ plays an important role to evaluate the impact of dependent variables to independent variables. The condition to choose the impact factors of function is that $\mathrm{R}^{2}$ is approximately 1 . For example, if the value of $\mathrm{R}^{2}$ is 0.997953 , then it means that $99.8 \%$ dependent variables have impact on independent ones. However, in order to decide if any independent variable is needed to function, then a $\mathrm{p}$-value test must be conducted. The condition to choose the value of $\mathrm{p}$-value is $p$-value $\leq 0.05$. If any independent variable has its $p$-value bigger than 0.05 ( $p>0.05)$, then that variable must be eliminated and testing process must be iterated to get higher accurate forecasted results.

\section{MAPE test}

Beside the stationary and co-integration test, a feasibility test based on historical time-series data of prediction function will be conducted by employing a Mean Absolute Percentage Error (MAPE) method to measure the accuracy of prediction. It has a fact that 
a relative error of a forecast can be measured by a MAPE, which could be expressed as:

$M A P E=\frac{1}{N} \sum_{n=1}^{N}\left|\frac{A_{N}-F_{N}}{A_{N}}\right| 100 \%$

Where $A_{n}$ is recorded consumption of the year $n ; F_{n}$ is forecasted consumption of the year $n$. It is noted that MAPE has an opposite principle with $\mathrm{R}^{2}$ as a lower computed MAPE will lead to higher reliable prediction, while a higher $\mathrm{R}^{2}$ could act the same meaning. MAPE is launched in this paper to evaluate the accuracy of forecast function and to compare with tolerance indicator values.

\section{Forecasting}

After building a standard function for predicting the electricity consumption of Vietnam industry and construction sectors, variable data and its corresponding historical data will then be obtained to import to the function. The consumption demand of Vietnam industry and construction sectors in the year 2020, 2025, and 2030 will be forecasted correspondingly afterward.

\section{Data}

\section{GDP of industry and construction sectors}

Vietnam is remarked as one of the most rapid growing countries in the world with the GDP growth rate at about 6.5\%/year in recent years; in which industry and construction sectors is the biggest contributor with the GDP growth rate is still maintained at a higher rate than the GDP of the entire economics. In 2011 , the GDP growth rate of industry and construction sectors reached $6.68 \%$ while the value of the national economics is recorded at $6.24 \%$; corresponding values in 2012 are $5.75 \%$ and $5.25 \%, 5.5 \%$ and $5.4 \%$ in 2013. The average values of the last three years are $6 \%$ and $5.4 \%$, correspondingly. There are three growing scenarios for Vietnam's GDP to 2035 have been released; in which the GDP growth rates in the low scenario are forecasted to reach 6.5\%/year in 20162025 and 6\%/year from 2026 to $2035^{9}$. These results are closely similar to forecasted growth rate of electricity consumption demands which are released by the Revised version of Master Plan N0. VII for Power System in Vietnam (PDP.VII rev.) ${ }^{9}$. This similarity can be used to demonstrated that GDP and electricity consumption demand could have a somehow correlation. The GDP data of industry and construction sectors will be cited from the PDP.VII rev.

\section{Income}

Income per person and person's electricity demand are confidentially believed to have a linear relation as the increase of person's incomes will lead to the higher needs of electric appliances and corresponding consumptions to improve the living conditions. For example at a low income condition, air conditioner and electric water heater could be dispensable. However, when the income is improved on enough to cover a high-cost electric bill, then they might be purchased to meet the demand of the house owners. It definitely leads to the more pressure on electric supply conditions. Therefore, the person's income is launched as an essential variable of forecasting model in this paper to quantify its relation with electricity demand ${ }^{10}$. The income per capita data will be collected from World Bank data source ${ }^{11}$.

\section{Proportion of industry and construction sec- tors's electricity consumption in total}

The 2017 report of EVN highlighted a rapid increase of proportion in total of electricity consumption needed for the industry, and construction sectors. It has been recorded to increase from $46.7 \%$ in 2005 to $51.9 \%$ in 2010 , and to $54.77 \%$ in 2015 . Also, it is remarked that the growth rate in the duration of 2010-2015 is lower than the ones recorded in the previous duration (2005-2010). However, the industry and construction sectors are still acting as the leading sector and contribute at a highest level in comparison with other sectors in economics. Data relevant to proportion of electricity consumption of industry and construction sectors are be referred from the PDP.VII rev.

\section{Electric tariff}

Electric tariff is an essential condition which impacts directly on every production in economics. In other words, electric tariff plays as a major input manufacturing cost of all sectors in economics. A number of studies on the impacts of electric tariff onto consumption behaviors have already been deployed in the last decades. However, it is really difficult to get an unanimity between those studies as the tariff policy is differed from countries to countries. Vietnam's electric tariff is identified as the lowest fare level in region and worldwide. Data involving national electric tariff will be obtained from EVN's database ${ }^{9}$.

\section{Collecting data in time series of 1990 to 2015}

After analyzing factors which could make influence on the electricity consumption of industry and construction sectors in Vietnam, then the historical records of those factors are assembled from various 
database sources. The more sufficient, reliable and long enough data, the more accurate forecasted results are. With a given time series data and $k$ represents for an independent variable of prediction model, then $(n$ $-k)>20^{12,13}$.

In this paper, GDP of industry and construction sectors, the proportion of industry and construction sectors in entire economics, income of person, and electric tariff will be brought into forecasting model as independent variables. Four independent variables will lead to $\mathrm{n}>20+4$.

In this paper, historical data from 1990 to 2015 are assembled and constructed as a time series order. This selected 26 values (equivalent to 26 years) time series is relatively long enough to be tested. The collected data are shown in Table 1.

\section{RESULTS}

\section{Converting variables into natural loga- rithms}

The input time series data will be converted into natural logarithm forms. Converted results are shown in Table 2.

\section{Testing}

\section{Stationary test}

A stationary test is conducted to test the stationary characteristics of data. Results shown in Table 3 indicate that all variables are non-stationary. As shown in Table 3, the p-value of almost variables are higher than $\alpha(\alpha=0.05)$. The only variable has the $\mathrm{p}$-value of lower than 0.05 is the GDP of industry and construction sectors $\left[\ln \left(G_{t}\right)\right]$. As all variables are nonstationary, a co-integration test will be employed to be conducted instead of computing a first difference calculation.

\section{Co-integration test}

Results of co-integration test are performed in Table 4 . The T-test results indicate that there are only four co-integration variables at the value of 0.05 . It is corresponding to the four mentioned non-stationary time series data.

\section{$R^{2}$ and $p$-value testing}

After conducting co-integration test, the coefficients of equation (2) are computed. Calculated results are performed in Table 5. The condition for choosing the coefficients of equation is that the $\mathrm{R}^{2}$ value is approximately 1 and $\mathrm{p}$-value of all variables are less than 0.05 . Table 5 shows the value of $\mathrm{R}^{2}$ testing of 0.992581 .
It means that $99.3 \%$ of dependent variables have impacts on independent ones. However, as p-value of $\ln P_{t}$ is above $0.05, \ln P_{t}$ is eliminated. Then all coefficients of equation will be recalculated in second time. Recalculated results are shown in Table 6; in which p-value of all variables are less than 0.05 .

\section{Eliminating inappropriate variables}

As $\ln P_{t}$ is eliminated, the equation (2) become: $\ln E C_{t}=\beta_{0}+\beta_{1} \ln G_{t}+\beta_{2} \ln I_{t}+\beta_{3} \ln X_{t}$ With $\beta_{0}, \beta_{1}, \beta_{2}$, and $\beta_{3}$ are $-5.05,0.372,0.623$, and 1.864, respectively. Then the equation (4) becomes: $\ln E C_{t}=-5.05+0.372 \ln G_{t}+0.623 \ln I_{t}+$ $1.864 \ln X_{t}$

That equation (5) is the qualified equation for forecasting.

\section{Comparison to historical data and evaluat- ing MAPE}

The equation (5) is launched to recalculate the electricity consumption in the past. Results are brought into a comparison with historical data to evaluate the accuracy of forecasting. Then a MAPE testing is applied with results are shown in Table 7 . It is realized that the MAPE has a value of $7.66 \%$. This value is noticeable as it is much lower than usual MAPE errors for long-term forecasting ${ }^{14}$. Therefore, if there is no significant fluctuation in economics and society, then the equation (5) could be a feasible forecasting tool for national power system.

\section{Forecast on electricity consumption of indus- try and construction sectors to 2030}

Forecasted value of GDP of industry and construction sectors, proportion of industry and construction sectors in entire economics, and income per capita of Vietnam to 2030 are collected and listed in Table $8^{9}$. As mentioned processing, those data will be converted into its corresponding natural logarithms. Then the equation (5) is applied to forecast the electricity consumption of Vietnam's industry and construction sectors in the future. Forecasted results are shown in Table 9.

The results show that: (1) in the low scenario, the electricity demand of the industry and construction sectors will reach 111,039 GWh, 167,945 GWh, and 227,634 GWh in 2020,2025, and 2030, respectively; (2) the forecasted values of the base scenario are 112,853 GWh in 2020, 172,691 GWh in 2025, and $242,027 \mathrm{GWh}$ in 2030; and (3) the corresponding predictions for high scenario in 2020, 2025, and 2030 are 115,947 GWh, 181,591 GWh, and 257,272 GWh, respectively. The vaules in high scenario in this study 


\begin{tabular}{|c|c|c|c|c|c|}
\hline Year & $\begin{array}{l}\text { Electricity con- } \\
\text { sumption }\end{array}$ & $\begin{array}{l}\text { GDP of the sec- } \\
\text { tor }\end{array}$ & $\begin{array}{l}\text { Proportion } \\
\text { consumption of } \\
\text { the sector }\end{array}$ & Income & Electric price \\
\hline & GWh & Billion US\$ & $\%$ & $\begin{array}{l}\text { US\$/ } \\
\text { person }\end{array}$ & $\begin{array}{l}\mathrm{VNĐ/} \\
\mathrm{kWh}\end{array}$ \\
\hline 1990 & 2,845 & $1,467.4$ & 46.0 & 130 & 640.0 \\
\hline 1991 & 3,080 & $2,287.4$ & 46.8 & 110 & 640.0 \\
\hline 1992 & 3,197 & $2,690.1$ & 46.1 & 130 & 640.0 \\
\hline 1993 & 3,477 & $3,809.3$ & 44.4 & 170 & 645.0 \\
\hline 1994 & 3,944 & $4,701.6$ & 42.5 & 200 & 645.0 \\
\hline 1995 & 4,614 & $5,962.9$ & 41.3 & 260 & 651.0 \\
\hline 1996 & 5,503 & $7,330.7$ & 41.1 & 310 & 667.0 \\
\hline 1997 & 6,163 & $8,610.1$ & 40.3 & 350 & 673.0 \\
\hline 1998 & 6,781 & $8,840.7$ & 38.4 & 360 & 684.0 \\
\hline 1999 & 7,590 & $9,894.4$ & 38.7 & 370 & 700.0 \\
\hline 2000 & 8,743 & $11,504.3$ & 41.6 & 400 & 718.0 \\
\hline 2001 & 10,503 & $12,514.3$ & 40.6 & 430 & 742.0 \\
\hline 2002 & 12,681 & $13,547.1$ & 41.9 & 460 & 752.0 \\
\hline 2003 & 15,290 & $15,665.7$ & 43.8 & 510 & 761.0 \\
\hline 2004 & 17,896 & $18,508.8$ & 45.1 & 590 & 774.0 \\
\hline 2005 & 21,302 & $21,976.2$ & 46.7 & 680 & 783.0 \\
\hline 2006 & 24,290 & $25,609.3$ & 47.4 & 760 & 789.0 \\
\hline 2007 & 29,212 & $29,813.6$ & 50.0 & 850 & 842.0 \\
\hline 2008 & 34,156 & $36,755.2$ & 50.7 & 1,000 & 948.5 \\
\hline 2009 & 38,504 & $39,637.0$ & 50.6 & 1,120 & 970.9 \\
\hline 2010 & 44,428 & $37,251.1$ & 51.9 & 1,270 & $1,058.0$ \\
\hline 2011 & 50,085 & $43,703.9$ & 52.9 & 1,390 & $1,242.0$ \\
\hline 2012 & 55,300 & $52,289.8$ & 52.4 & 1,550 & $1,437.0$ \\
\hline 2013 & 60,773 & $56,828.7$ & 52.7 & 1,740 & $1,508.8$ \\
\hline 2014 & 69,185 & $61,846.7$ & 53.9 & 1,900 & $1,508.8$ \\
\hline 2015 & 76,795 & $64,252.8$ & 52.6 & 1,990 & $1,622.0$ \\
\hline
\end{tabular}




\begin{tabular}{llllll}
\multicolumn{5}{c}{ Table 2: Converted results into natural logarithms } \\
\hline & $\ln \left(E C_{t}\right)$ & $\ln \left(G_{t}\right)$ & $\ln \left(X_{t}\right)$ & $\ln \left(I_{t}\right)$ & $\ln \left(P_{t}\right)$ \\
1990 & 7.95 & 7.29 & 3.83 & 4.87 & 6.46 \\
1991 & 8.03 & 7.74 & 3.85 & 4.70 & 6.46 \\
1992 & 8.07 & 7.90 & 3.83 & 4.87 & 6.46 \\
1993 & 8.15 & 8.25 & 3.79 & 5.14 & 6.47 \\
1994 & 8.28 & 8.46 & 3.75 & 5.30 & 6.47 \\
1995 & 8.44 & 8.69 & 3.72 & 5.56 & 6.48 \\
1996 & 8.61 & 8.90 & 3.72 & 5.74 & 6.50 \\
1997 & 8.73 & 9.06 & 3.70 & 5.86 & 6.51 \\
1998 & 8.82 & 9.09 & 3.65 & 5.89 & 6.53 \\
1999 & 8.93 & 9.20 & 3.66 & 5.91 & 6.55 \\
2000 & 9.08 & 9.35 & 3.73 & 5.99 & 6.58 \\
2001 & 9.26 & 9.43 & 3.70 & 6.06 & 6.61 \\
2002 & 9.45 & 9.51 & 3.74 & 6.13 & 6.62 \\
2003 & 9.63 & 9.66 & 3.78 & 6.23 & 6.63 \\
2004 & 9.79 & 9.83 & 3.81 & 6.38 & 6.65 \\
2005 & 9.97 & 10.00 & 3.84 & 6.52 & 6.66 \\
2006 & 10.10 & 10.15 & 3.86 & 6.63 & 6.67 \\
2007 & 10.28 & 10.30 & 3.91 & 6.75 & 6.74 \\
2008 & 10.44 & 10.51 & 3.93 & 6.91 & 6.85 \\
2009 & 10.56 & 10.59 & 3.92 & 7.02 & 6.88 \\
2010 & 10.70 & 10.53 & 3.95 & 7.15 & 6.96 \\
2011 & 10.82 & 10.69 & 3.97 & 7.24 & 7.12 \\
2015 & 10.92 & 10.86 & 3.96 & 7.35 & 7.27 \\
\hline & 11.01 & 10.95 & 3.96 & 7.46 & 7.32 \\
\hline & 11.14 & 11.03 & 3.99 & 7.55 & 7.32 \\
\hline & 11.07 & 3.96 & 7.60 & 7.39 \\
\hline
\end{tabular}

Table 3: Stationary test of forecasting equation

\begin{tabular}{lllll}
\hline Variable & ADF Test & & P-P Test & \\
& T. statistic & Prob. value & T. statistic & Prob. Value \\
$\ln E C_{t}$ & -0.556033 & 0.8630 & 0.419163 & 0.9797 \\
$\ln G_{t}$ & -4.154082 & 0.0037 & -4.154082 & 0.0037 \\
$\ln I_{t}$ & -2.815066 & 0.0711 & -0.475247 & 0.8805 \\
$\ln X_{t}$ & -2.271965 & 0.1893 & -0.395858 & 0.8955 \\
$\ln P_{t}$ & 2.593966 & 1 & 2.324744 & 0.9999 \\
\hline
\end{tabular}




\begin{tabular}{lllll}
\hline \multicolumn{4}{l}{ Table 4: Co-Integration test } \\
\cline { 2 - 5 } & Hypothesized & Trace Statistic & Critical Value & Prob. \\
None * & 107.4064 & 69.81889 & 0.0000 \\
At most 1 * & 68.64893 & 47.85613 & 0.0002 \\
At most 2 * & 37.34043 & 29.79707 & 0.0056 \\
At most 3 * & 15.94579 & 15.49471 & 0.0427 \\
At most 4 & 2.010153 & 3.841466 & 0.1562 \\
\hline
\end{tabular}

Table 5: Results of the first calculation

\begin{tabular}{|c|c|c|c|c|}
\hline Variable & Coefficient & Std. Error & $\mathrm{t}$-Statistic & Prob. \\
\hline $\mathrm{C}$ & -4.798612 & 1.197327 & -4.007772 & 0.0006 \\
\hline $\ln G_{t}$ & 0.339614 & 0.165795 & 2.048397 & 0.0500 \\
\hline $\ln I_{t}$ & 0.686921 & 0.241594 & 2.843290 & 0.0097 \\
\hline $\ln P_{t}$ & -0.093344 & 0.218511 & -0.427181 & 0.6736 \\
\hline $\ln X_{t}$ & 1.941250 & 0.328647 & 5.906802 & 0.0000 \\
\hline $\mathrm{R}^{2}$ & & 0.992581 & & \\
\hline
\end{tabular}

Table 6: Results of the second calculation

\begin{tabular}{lllll}
\hline Variable & Coefficient & Std. Error & t-Statistic & Prob. \\
$\mathrm{C}$ & -5.050521 & 1.022495 & -4.939411 & 0.0001 \\
$\ln G_{t}$ & 0.372298 & 0.144326 & 2.579560 & 0.0171 \\
$\ln I_{t}$ & 0.623799 & 0.187552 & 3.326022 & 0.0031 \\
$\ln X_{t}$ & 1.864202 & 0.269579 & 6.915226 & 0.0000 \\
$\mathrm{R}^{2}$ & & 0.992516 & & \\
\hline
\end{tabular}

are less than from $9.0 \%$ to $15.8 \%$ of that of the based of in the Revised version of master plan N0. VII ${ }^{9}$.

\section{CONCLUSION \& DICUSSION}

In this paper, an econometric model namely Cobb Douglas production function has been applied to forecast the electricity consumption of Vietnam's industry and construction sectors to 2030. Four variables have been identified as: (1) GDP of industry and construction sectors; (2) income per person; (3) proportion of the industry and construction sectors in entire economics (GDP); and (4) electricity price. Three testing methods have been launched to build the most reliable and highest accuracy prediction equation, they are: (1) stationary testing; (2) cointegration testing; and (3) $\mathrm{R}^{2}$ and p-value testing.

The equation (5) has the MAPE has a value of $7.66 \%$. This value is a very good MAPE error for long-term forecasting. There are three qualified variables (GDP of the industry and construction sectors, proportion of industry and construction sectors in entire economics and income per person) have been figuredout. It means that the electricity price has no impacts on the electricity consumption behaviors of Vietnam's industry and construction sectors. It can be explained that Vietnam's electricity tariff has been fixed based on national policy. Additionally, there is a number of manufacturing industries is currently provided with special subsidy-tariff policies. The demand of Vietnam's the industry and construction sectors in 2030 will be doubled in comparison with the values of 2020 and tripled to the consumption of $2016(85,305$ GWh). For this reason, it is an urgent issue to release an appropriate investment on national power system. Moreover, variable of electric price does not effect to the demand. This is a very critical result of the study for authority governors in Vietnam.

There is very common that forecating of MOIT (PDP.VII rev.) are always higher than real one. 
Table 7: Results of the mape testing for the forecasting equation (5)

\begin{tabular}{|c|c|c|c|}
\hline Year & Consumption by euqation (5) & $\begin{array}{l}\text { Historical data of con- } \\
\text { sumption }\end{array}$ & Error \\
\hline Unit & GWh & GWh & $\%$ \\
\hline 1990 & $2,530.755$ & 2,845 & 11,0 \\
\hline 1991 & $2,777.509$ & 3,080 & 9,8 \\
\hline 1992 & $3,183.654$ & 3,197 & 0,4 \\
\hline 1993 & $3,994.011$ & 3,477 & $-14,9$ \\
\hline 1994 & $4,406.035$ & 3,944 & $-11,7$ \\
\hline 1995 & $5,374.738$ & 4,614 & $-16,5$ \\
\hline 1996 & $6,418.859$ & 5,503 & $-16,6$ \\
\hline 1997 & $7,086.356$ & 6,163 & $-15,0$ \\
\hline 1998 & $6,656.287$ & 6,781 & 1,8 \\
\hline 1999 & $7,163.889$ & 7,590 & 5,6 \\
\hline 2000 & $9,101.820$ & 8,743 & $-4,1$ \\
\hline 2001 & $9,389.121$ & 10,503 & 10,6 \\
\hline 2002 & $10,696.150$ & 12,681 & 15,7 \\
\hline 2003 & $13,078.730$ & 15,290 & 14,5 \\
\hline 2004 & $16,094.380$ & 17,896 & 10,1 \\
\hline 2005 & $20,003.750$ & 21,302 & 6,1 \\
\hline 2006 & $23,335.400$ & 24,290 & 3,9 \\
\hline 2007 & $29,250.450$ & 29,212 & $-0,1$ \\
\hline 2008 & $35,912.550$ & 34,156 & $-5,1$ \\
\hline 2009 & $39,496.170$ & 38,504 & $-2,6$ \\
\hline 2010 & $43,764.510$ & 44,428 & 1,5 \\
\hline 2011 & $50,915.380$ & 50,085 & $-1,7$ \\
\hline 2012 & $57,235.370$ & 55,300 & $-3,5$ \\
\hline 2013 & $64,131.260$ & 60,773 & $-5,5$ \\
\hline 2014 & $72,913.230$ & 69,185 & $-5,4$ \\
\hline 2015 & $72,736.170$ & 76,795 & 5,3 \\
\hline MAPE & & & 7.66 \\
\hline
\end{tabular}

\section{ABBREVIATION}

GDP: Gross Domestic Production

EVN: Vietnam Electricity

MOIT: Ministry of Industry and Trade

PDP.VII rev.: Revised version of Master Plan N0. VII for Power System in Vietnam

MAPE: Mean Absolute Percentage Error

ANN: Artificial Neural Networks

ADF: Augmented Dickey Fuller
P-P: Phillips-Perron

\section{CONFLICT OF INTEREST}

Group of authors have no conflict on interest in publishing of the paper. 
Table 8: Forecasted values of the proportion in GDP of the sectors in total, and income per person to $2030^{9}$

\begin{tabular}{lll|ll}
\hline Variable & Scenario & 2020 & 2025 & 2030 \\
\hline Income per person [US\$/yr] & Low Scenario & 3,307 & 4,939 & 7,205 \\
& Base Scenario & 3,370 & 5,111 & 7,836 \\
& High Scenario & 3,485 & 5,450 & 8,450 \\
\hline Proportion of the sectors [\%] & & 55.48 & 60.35 & 62.39 \\
GDP of the sectors [\%] & Low Scenario & 65,428 & 66,603 & 67,779 \\
& Base Scenario & 66,212 & 67,779 & 69,424 \\
\hline & High Scenario & 67,309 & 69,659 & 72,089 \\
\hline
\end{tabular}

Table 9: Forecast on the electricity consumption of the sectors to 2030 [GWh]

\begin{tabular}{lccc}
\hline & 2020 & 2025 & 2030 \\
Low Scenario & 111,039 & 167,945 & 227,634 \\
Base Scenario & 112,853 & 172,691 & 242,027 \\
High Scenario & 115,947 & 181,591 & 257,272 \\
Revised version of master plan n0. VII ${ }^{9}$ & & 305,712 \\
Base Scenario & 127,380 & 206,446 & \\
\hline
\end{tabular}

\section{AUTHOR CONTRIBUTION}

Viet-Cuong VO, who deliver ideal, method, and data of the study. Correcting the manuscript.

Hoang-Phuong NGUYEN, who running the program.

Le-Duy-Luan NGUYEN, who draft the manuscript. Van-Hung PHAM, who do the first try of the program.

\section{REFERENCES}

1. Vietnam Electricity (EVN), Vietnam Power 2015 Report. 2015;

2. Ozoh P, Abd-Rahman S, Labadin J, Apperley M. A Comparative Analysis of Techniques for Forecasting Electricity Consumption. International Journal of Computer Applications. 2014;88(15). Available from: https://doi.org/10.5120/154263841.

3. Husain S, Islam MS. A Test for the Cobb Douglas Production Function in Manufacturing Sector: The Case of Bangladesh. International Journal of Business and Economics Research. 2016;5(5):149-154. Available from: https://doi.org/10.11648/ j.ijber.20160505.13.

4. Imtiaz AK, Norman BM, Amran MR, Saleem M, Wahab NIA, Mohibullah. Evaluation and Forecasting of Long Term Electricity Consumption Demand for Malaysia by Analysis. The First International Power and Energy Conference PECon 2006, Putrajaya, Malaysia. 2006;Available from: https://doi.org/10.1109/ PECON.2006.346658.

5. Muhammad S, Hooi HL. The dynamics of electricity consumption and economic growth: A revisit study of their causal- ity in Pakistan. Energy. 2012;39:146-153. Available from: https://doi.org/10.1016/j.energy.2012.01.048.

6. Jiahai $Y$, Changhong $Z$, Shunkun $Y$, Zhaoguang $H$. Electricity consumption an economic growth in China: Cointegration and co-feature analysis. Energy Economics. 2007;29:11791191. Available from: https://doi.org/10.1016/j.eneco.2006.09. 005.

7. Nguyen VMH, Nguyen KTP, Vo CV, Phan BTT. Forecast on 2030 Vietnam Electricity Consumption. Engineering, Technology \& Applied Science Research. 2018;8(3):2869-2874. Available from: https://doi.org/10.1109/ICELTICS.2017.8253238PMCid: PMC5341203.

8. Robert FE, Granger CWJ. Co-integration and Error Correction: Representation, Estimation, and Testing. Econometrica. 1987;55(2):251-276. Available from: https://doi.org/10.2307/ 1913236.

9. Institute of Energy, MOIT, "Revised version of master plan NO. VII for power system in Vietnam". 2016;.

10. General Statistics Office of Vietnam, "Master investigation on populayion and households 2014 - Vietnam". 2014;.

11. Data world bank;Available from: http://data.worldbank.org/ country/vietnam.

12. Green SB. How many subjects does it take to do a regression analysis? Multivariate Behavioral Research. 1991;26:499510. PMID: 26776715. Available from: https://doi.org/10.1207/ s15327906mbr2603_7.

13. Barbara GT, Linda SF. Using multivariate statistics 5th Edn. California State University, Northridge, Pearson Education Inc. 2007;.

14. Amstrong, Scott J. Long-Range Forecasting: From Crystal Ball to Computer. Wiley-Interscience; Second edition. 1985;. 


\title{
Mô hình kinh tế lượng dự báo nhu cầu điện năng của ngành công nghiệp và xây dựng tại Việt Nam đến 2030
}

\author{
Võ Viết Cường ${ }^{1, *}$, Nguyễn Hoàng Phương ${ }^{1,2}$, Nguyễn Lê Duy Luân ${ }^{3}$, Phạm Văn Hùng1
}

${ }^{1}$ Truiơng Đại học Sui pham Kỹ thuật Tp. HCM, Số 1 , Võ Văn Ngân, Quận Thủ Đức, Tp. HCM, Việt Nam

${ }^{2}$ Truờng Đại học Tiền Giang, Số 119, Ấp Bắc, Phuiơng 5, Tp. Mỹ Tho, Tỉnh Tiên Giang, Việt Nam

${ }^{3}$ Trường Đại học Kiến trúc Tp. HCM, Số 196, Pasteur, Quận 3, Tp. HCM, Việt

Nam

Liên hệ

Võ Viết Cường, Trường Đại học Sư phạm Kỹ thuật Tp. HCM, Số 1, Võ Văn Ngân, Quận Thủ Đức, Tp. HCM, Việt Nam

Email: cuongvv@hcmute.edu.vn

Lịch sử

- Ngày nhận: 15-12-2019

- Ngày chấp nhận: 13-3-2020

- Ngày đăng: 31-3-2020

DOI : 10.32508/stdjet.v3i1.646

\section{Check for updates}

\section{Bản quyền}

๑ ĐHQG Tp.HCM. Đây là bài báo công bố mở được phát hành theo các điều khoản của the Creative Commons Attribution 4.0 International license.

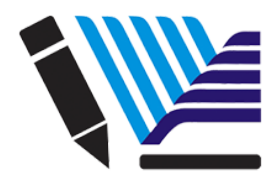

VNU-HCM Press

\section{TÓM TẮT}

Dự báo chính xác nhu cầu điện dài hạn có vai trò rất quan trọng cho quy hoạch hệ thống điện tại bất kỳ quốc gia nào. Việt Nam là một trong những nước có kinh tế phát triển nhanh nhất thế giới, nhu cầu điện tăng trung bình khoảng 15\%/năm trong suốt ba thập kỷ vừa qua. Sự đóng góp của ngành công nghiệp và ngành xây dựng trong GDP tăng đều qua các năm, và hiện đang giữ tỷ trọng lớn nhất trong tiêu thụ điện với tỷ lệ trên $50 \%$ phụ tải quốc gia. Làm sao để xác dịnh chính xác tiêu thụ điện của những lĩnh vực trên góp phần quan trọng cho việc quy hoạch hệ thống điện. Bài báo này đề xuất áp dụng mô hình kinh tế lượng với hàm sản xuất Cobb Douglas để dự báo nhu cầu điện của ngành công nghiệp và ngành xây dựng Việt Nam tới năm 2030. Bốn biến được sư dụng là giá trị trong GDP của hai ngành trên, thu nhập đầu người, tỷ trọng điện năng tiêu thụ của 2 ngành trong tổng nhu cầu của nền kinh tế, và giá điện. Kết quả dự báo cho thấy phương pháp đề xuất có sai số MAPE ở mức khá thấp là 7,66\%. Biến giá điện không tác động đến nhu cầu điện của 2 ngành. Đây là kết quả có giá trị của nghiên cứu cho các nhà quả lý tại Việt Nam. Nhu cầu điện theo kịch bản cơ sở của GDP và thu nhập đầu người được dư báo lần lượt là $112.853 \mathrm{GWh}$, 172.691 GWh, và 242.027 GWh tương ứng với các năm 2020, 20205, và 2030. Với kịch bản cao, nhu cầu tương ứng là $115.947 \mathrm{GWh}, 181.591 \mathrm{GWh}$, và $257.272 \mathrm{GWh}$. Những giá trị của kịch bản cao thấp hơn từ 9,0\% đến 15,8\% so với giá trị tương ứng trong kịch bản cơ sở của Tông Sơ đồ 7 hiệu chỉnh. Từ khoá: Dự báo, Mô hình kinh tế lượng, Nhu cầu điện, Hàm sản xuất Cobb Douglas, Ngành công nghiệp \& xây dựng
Trích dẫn bài báo này: Viết Cường $\mathrm{V}$, Hoàng Phương $\mathrm{N}$, Lê Duy Luân $\mathrm{N}$, Văn Hùng $\mathrm{P}$. Mô hình kinh tế lượng dự báo nhu cầu điện năng của ngành công nghiệp và xây dựng tại Việt Nam đến 2030. Sci. Tech. Dev. J. - Eng. Tech.; 3(1):316-325. 